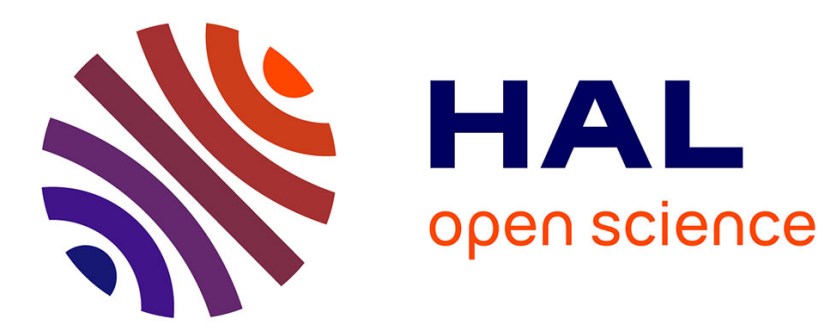

\title{
Effect of haplotypes on the pharmacokinetics and renin-inhibiting effect of aliskiren
}

Tuija Tapaninen, Pertti J. Neuvonen, Mikko Niemi

\section{To cite this version:}

Tuija Tapaninen, Pertti J. Neuvonen, Mikko Niemi. Effect of haplotypes on the pharmacokinetics and renin-inhibiting effect of aliskiren. European Journal of Clinical Pharmacology, 2010, 66 (9), pp.865-870. 10.1007/s00228-010-0836-z . hal-00594969

\section{HAL Id: hal-00594969 \\ https://hal.science/hal-00594969}

Submitted on 23 May 2011

HAL is a multi-disciplinary open access archive for the deposit and dissemination of scientific research documents, whether they are published or not. The documents may come from teaching and research institutions in France or abroad, or from public or private research centers.
L'archive ouverte pluridisciplinaire HAL, est destinée au dépôt et à la diffusion de documents scientifiques de niveau recherche, publiés ou non, émanant des établissements d'enseignement et de recherche français ou étrangers, des laboratoires publics ou privés. 


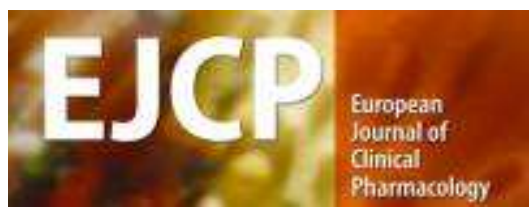

\section{Effect of ABCB1 haplotypes on the pharmacokinetics and renin-inhibiting effect of aliskiren}

\begin{tabular}{|c|c|}
\hline Journal: & European Journal of Clinical Pharmacology \\
\hline Manuscript ID: & EJCP-2010-0093.R1 \\
\hline Type of submission: & Original \\
\hline $\begin{array}{r}\text { Date Submitted by the } \\
\text { Author: }\end{array}$ & 21-Apr-2010 \\
\hline Complete List of Authors: & $\begin{array}{l}\text { Tapaninen, Tuija; University of Helsinki, Department of Clinical } \\
\text { Pharmacology } \\
\text { Neuvonen, Pertti; University of Helsinki, Department of Clinical } \\
\text { Pharmacology } \\
\text { Niemi, Mikko; University of Helsinki and Helsinki University Central } \\
\text { Hospital, Department of Clinical Pharmacology }\end{array}$ \\
\hline
\end{tabular}

\section{S ScholaroNe




\title{
Effect of $A B C B 1$ haplotypes on the pharmacokinetics and
}

\author{
renin-inhibiting effect of aliskiren
}

\author{
Tuija Tapaninen, Pertti J. Neuvonen and Mikko Niemi \\ Department of Clinical Pharmacology, University of Helsinki and Helsinki University \\ Central Hospital, Helsinki, Finland \\ Correspondence and requests for reprints: \\ Mikko Niemi, MD \\ Department of Clinical Pharmacology, \\ Helsinki University Central Hospital \\ PO Box 705, FI-00029 HUS, Finland \\ Fax: +358-9-471 74039 \\ E-mail: mikko.niemi@helsinki.fi
}

Word count: 2153 words (excluding the title page, summary, references, tables, and figures)

A revised manuscript (EJCP 2010-0093) for European Journal of Clinical

Pharmacology, including 21 pages, 1 table, and 1 figure (April 2010). 


\begin{abstract}
Purpose

This study aimed to investigate possible effects of $A B C B 1$ haplotypes on the pharmacokinetics and renin-inhibiting effect of aliskiren.
\end{abstract}

\title{
Methods
}

Eleven healthy volunteers homozygous for the $A B C B 1$ c.1236C-c.2677G-c.3435C

(CGC) haplotype and eleven homozygous for the c.1236T-c.2677T-c.3435T (TTT) haplotype ingested a single 150-mg dose of aliskiren. Plasma aliskiren concentrations were measured up to $72 \mathrm{~h}$, its excretion into urine up to $12 \mathrm{~h}$, and plasma renin activity up to $24 \mathrm{~h}$.

\section{Results}

The $A B C B 1$ haplotypes had no significant effect on the pharmacokinetics or renininhibiting effect of aliskiren. The geometric mean ratio (95\% confidence interval) of aliskiren peak plasma concentration and area under the plasma concentration-time curve from $0 \mathrm{~h}$ to infinity in participants homozygous for the TTT haplotype to those in participants homozygous for the CGC haplotype were $1.14(0.66,1.96 ; P=0.631)$ and $1.01(0.58,1.76 ; P=0.960)$, respectively.

\section{Conclusions}

These data suggest that the $A B C B 1$ c.1236C-c.2677G-c.3435C and c.1236T-c.2677Tc.3435T haplotypes have no clinically meaningful effect on the pharmacokinetics of aliskiren.

\section{KEYWORDS}

Pharmacokinetics, Pharmacogenetics, $A B C B 1$ haplotypes, Aliskiren 


\section{INTRODUCTION}

The direct renin inhibitor aliskiren is poorly absorbed and has a low oral bioavailability of 2-3\% [1]. Aliskiren is mainly eliminated by biliary excretion [1]. In addition, about $0.4 \%$ of the oral dose is excreted unchanged into urine and about $1.4 \%$ undergoes oxidative biotransformation via CYP3A4 [1]. Aliskiren is a substrate of P-glycoprotein (also known as ABCB1) [2], an efflux transporter expressed in tissues with an excretory or barrier function [3, 4]. The P-glycoprotein and CYP3A4 inhibitors, itraconazole and cyclosporine [5-9], have raised the area under the plasma concentration-time curve (AUC) of aliskiren by about 6.5-fold and 5-fold, respectively [10, 11], supporting a major role of P-glycoprotein in limiting the intestinal absorption of aliskiren. Moreover, rifampicin, an inducer of P-glycoprotein and CYP3A4 [12, 13], has reduced the AUC of aliskiren by $56 \%$ [14].

A common synonymous single nucleotide polymorphism (SNP) in the $A B C B 1$ gene encoding P-glycoprotein, c.3435C > T, has been variably associated with reduced expression and function of P-glycoprotein in vitro and increased plasma concentrations of P-glycoprotein substrate drugs in vivo [15-17]. The mechanism underlying these associations is not completely understood, but it has been suggested that c. $3435 \mathrm{C}>\mathrm{T}$ affects $A B C B 1$ mRNA stability [18]. Alternatively, the associations may be explained by linkage disequilibrium between c. $3435 \mathrm{C}>\mathrm{T}$ and a functional sequence variation, or that c.3435C $>\mathrm{T}$ and sequence variations in linkage disequilibrium with it form a haplotype conferring altered P-glycoprotein activity $[16,19]$. The $A B C B 1$ c.3435C $>\mathrm{T}$ 
$\mathrm{SNP}$ is in strong linkage disequilibrium with the c.1236C $>\mathrm{T}$ (synonymous) and c.2677G >T/A (p.Ala893Ser/Thr) SNPs within the same gene $[17,19,20]$.

The variant alleles c.1236T, c.2677T, and c.3435T are common in Europeans and European Americans, with reported frequencies of occurrence ranging from 39 to $46 \%$, 39 to $47 \%$, and 54 to $60 \%$, respectively [17, 19-22]. In the Finnish population, the two most common haplotypes based on these SNPs are c.1236T-c.2677T-c.3435T (TTT) and c.1236C-c.2677G-c.3435C (CGC), with frequencies of $42.7 \%$ and $34.4 \%$, respectively [17]. The $A B C B 1$ TTT haplotype has been associated, for example, with increased plasma concentrations of and enhanced lipid-lowering response to simvastatin (acid) and atorvastatin, compared with the $A B C B 1$ CGC haplotype [17, 23, 24].

Considerable interindividual variability exists in the pharmacokinetics of aliskiren [25], but the background of this variability is unknown. Our hypothesis was that genetic variability in $A B C B 1$ affects the pharmacokinetics of aliskiren. Therefore, we investigated the effects of the $A B C B 1 \mathrm{CGC}$ and TTT haplotypes on the pharmacokinetics and pharmacodynamics of aliskiren. 


\section{METHODS}

\section{Subjects}

Twenty-two healthy White Finnish volunteers participated in this study after giving written informed consent. They were recruited from a group of more than 700 subjects genotyped for the $A B C B 1$ c.1236C $>\mathrm{T}$ (rs1128503), c.2677G >T/A (rs2032582), and c.3435C > T (rs1045642) SNPs [17]. To minimize variability in aliskiren pharmacokinetics due to other genetic variants, all subjects were genotyped for the functionally significant $A B C B 1$ c.1199G>A (p.Ser400Asn; rs2229109) [17] and CYP3A5*3 (g.6986A $>\mathrm{G}$; rs776746) [26] alleles and only noncarriers of the $A B C B 1$ c.1199A and CYP3A5 g.6986A (CYP3A5 expressor) alleles were recruited.

Four women and seven men homozygous for the $A B C B 1$ CGC haplotype, mean $\pm \mathrm{SD}$ age $26 \pm 4$ years (range, 22-37 years), height $178 \pm 9 \mathrm{~cm}(158-189 \mathrm{~cm})$, and weight $74 \pm$ $11 \mathrm{~kg}(63-95 \mathrm{~kg})$, and five women and six men homozygous for the TTT haplotype, age $24 \pm 2$ years $(21-27$ years), height $175 \pm 10 \mathrm{~cm}(158-186 \mathrm{~cm})$, and weight $69 \pm 12 \mathrm{~kg}$ (51-94 kg), participated in the study. Each participant's health was ascertained by medical history, clinical examination, and laboratory tests. None was on any continuous medication and none was a tobacco smoker.

\section{Study design}

The study protocol was approved by the Coordinating Ethics Committee of the Helsinki and Uusimaa Hospital District, and the National Agency for Medicines. Following an overnight fast, the subjects ingested a single 150-mg dose of aliskiren (Rasilez; 
Novartis, Horsham, UK) with $150 \mathrm{ml}$ water. A standardized warm meal was served $4 \mathrm{~h}$ after aliskiren, and a standardized light meal after $7 \mathrm{~h}$ and $10 \mathrm{~h}$. As a safety assessment, systolic and diastolic blood pressures were measured from the forearm with an automatic oscillometric blood pressure monitor (Omron M5-I, Omron Healthcare Europe BV, Hoofddorp, The Netherlands), with the participant in a sitting position, prior to and 2, 4, 7, 9, 12, and $24 \mathrm{~h}$ after aliskiren ingestion. The participants were under direct medical supervision for $12 \mathrm{~h}$ after the administration of aliskiren. No significant differences in blood pressures were observed between the haplotype groups (data not shown). Use of other drugs was prohibited for one week and use of grapefruit products for three days before aliskiren administration and $72 \mathrm{~h}$ thereafter.

Timed blood samples (5 or $10 \mathrm{ml}$ each) for aliskiren concentration measurements were drawn into tubes containing ethylenediaminetetraacetic acid (EDTA) prior to and $0.5,1$, $2,3,4,5,7,9,12,24,34,48$, and $72 \mathrm{~h}$ after aliskiren administration. Blood samples for the determination of plasma renin activity $(5 \mathrm{ml}$ each) were drawn before the administration of aliskiren and $4 \mathrm{~h}$ and $24 \mathrm{~h}$ thereafter into chilled EDTA tubes, which were placed on ice immediately after sampling. Plasma was separated within $30 \mathrm{~min}$. Urine was collected up to $12 \mathrm{~h}$ after aliskiren ingestion. Urine aliquots and plasma were stored at $-70^{\circ} \mathrm{C}$ until analysis.

\section{Determination of aliskiren concentrations and renin activity}

Plasma concentrations of aliskiren were quantified by use of solid phase extraction and liquid chromatography-tandem mass spectrometry (LC/MS/MS) [10]. An aliquot of 700 $\mu \mathrm{l}$ of each plasma sample was mixed with $100 \mu \mathrm{l}$ of $10 \%$ phosphoric acid and $50 \mu \mathrm{l}$ 
internal standard solution (1000 ng/ml acebutolol in 1:1 methanol:water). Then the mixture was loaded to the extraction cartridge (Oasis MCX 1cc/30 mg, Waters, Milford, MA, USA), which had been pre-conditioned with $1 \mathrm{ml}$ of methanol and $1 \mathrm{ml}$ of $1 \%$ acetic acid. The cartridge was subsequently washed with $1 \mathrm{ml}$ of methanol and $1 \mathrm{ml}$ of $1 \%$ acetic acid. The analytes were eluted out with two times $0.6 \mathrm{ml}$ of $2 \%$ ammonium hydroxide in methanol. The eluent was dried at $50^{\circ} \mathrm{C}$ under a nitrogen stream. The residue was dissolved in $100 \mu \mathrm{l}$ of the mobile phase, and $15 \mu \mathrm{l}$ of the sample was injected to the LC/MS/MS system. The chromatographic separation was carried out on an AtlantisT3 column $(2.1 \times 100 \mathrm{~mm}, 3 \mu \mathrm{m})$ protected by an AtlantisT3 $(2.1 \times 10 \mathrm{~mm}, 3$ $\mu \mathrm{m}$ ) guard cartridge (Waters). The mobile phase consisted of (A) $2 \mathrm{mmol} / \mathrm{l}$ ammonium acetate ( $\mathrm{pH} 4.90)$ and (B) methanol. The total running time was 15 minutes with the mobile phase gradient of 0.5 minutes at $70 \% \mathrm{~A}, 0.5$ minutes to $5 \% \mathrm{~A}, 3$ minutes at $5 \%$ A, 0.1 minutes to $70 \% \mathrm{~A}$, and 10.9 minutes at $70 \% \mathrm{~A}$. The flow rate of the mobile phase was $250 \mu \mathrm{l} / \mathrm{min}$. The column temperature was $40^{\circ} \mathrm{C}$. Mass spectra were obtained using an Applied Biosystems SCIEX API 2000 Q Trap mass spectrometer operated in positive ion mode (Sciex Division of MDS Inc, Toronto, ON, Canada). The ion transitions were mass-to-charge ratio (m/z) 552.4 to m/z 436.3 for aliskiren and m/z 337.3 to $\mathrm{m} / \mathrm{z} 116.3$ for acebutolol.

For the determination of aliskiren concentrations in urine, an aliquot of $300 \mu$ of each urine sample was mixed with $300 \mu \mathrm{l}$ of fresh frozen plasma, $100 \mu 1$ of $10 \%$ phosphoric acid, and $50 \mu \mathrm{l}$ internal standard solution $(1000 \mathrm{ng} / \mathrm{ml}$ acebutolol in 1:1 methanol:water). The extraction, chromatographic separation, and mass spectrometric detection were performed as described for plasma aliskiren. The lower limit of 
quantification was $0.25 \mathrm{ng} / \mathrm{ml}$ for plasma and $9 \mathrm{ng} / \mathrm{ml}$ for urine aliskiren. The calibration curve for plasma aliskiren was linear over the range $0.25-500 \mathrm{ng} / \mathrm{ml}$ ( $r>0.999$, weighting 1/x) and for urine aliskiren over the range $9-1800 \mathrm{ng} / \mathrm{ml}(\mathrm{r}>0.999$, weighting $1 / \mathrm{x})$. The extraction recoveries were $>80 \%$. The intra-day coefficients of variation were $\leq 1.2 \%$ at relevant concentrations in plasma and $\leq 4.8 \%$ in urine $(n=6)$. Plasma renin activity was determined by radioimmunoassay of generated angiotensin I with a commercially available method (RENCTK; DiaSorin, Saluggia, Italy) at HUSLAB laboratory (Helsinki, Finland).

\section{Pharmacokinetics and pharmacodynamics}

Aliskiren pharmacokinetics were characterized by peak plasma concentration $\left(\mathrm{C}_{\max }\right)$, time to $\mathrm{C}_{\max }\left(\mathrm{t}_{\max }\right)$, elimination half-life $\left(\mathrm{t}_{1 / 2}\right), \mathrm{AUC}_{0-72}, \mathrm{AUC}_{0-\infty}$, the amount of aliskiren excreted into urine from 0 to $12 \mathrm{~h}(\mathrm{Ae})$, and the renal clearance $\left(\mathrm{Cl}_{\text {renal }}\right)$.

Pharmacokinetic parameters were calculated with non-compartmental methods using MK-Model, version 5.0 (Biosoft, Cambridge, UK). The terminal log-linear part of each concentration-time curve was identified visually. The elimination rate constant $\left(\mathrm{k}_{\mathrm{e}}\right)$ was determined by linear regression analysis of the log-linear part of the plasma drug concentration-time curve. The $t_{1 / 2}$ was calculated by the equation $t_{1 / 2}=\ln 2 / k_{e}$. The AUC values were calculated by a combination of the linear and log-linear trapezoidal rules with extrapolation to infinity, when appropriate, by division of the last measured concentration by $\mathrm{k}_{\mathrm{e}}$. The $\mathrm{Cl}_{\text {renal }}$ of aliskiren was calculated by the equation $\mathrm{Cl}_{\text {renal }}=\mathrm{Ae} / \mathrm{AUC}_{0-12}$. Aliskiren pharmacodynamics were characterized by plasma renin activity at $4 \mathrm{~h}$ and $24 \mathrm{~h}$ after aliskiren intake. 


\section{Statistical analysis}

The data were analyzed using SPSS 17.0 (SPSS, Chicago, IL, USA). The $\mathrm{C}_{\max }$, AUC, $\mathrm{Ae}$, and $\mathrm{Cl}_{\text {renal }}$ data were logarithmically transformed before statistical analysis. Statistical comparisons were made between the $A B C B 1$ haplotypes using analysis of variance (ANOVA). Body weight was set as a covariate for $\mathrm{C}_{\max }$, AUC, and Ae [27]. The $t_{\max }$ data were compared with the Mann-Whitney test. Differences were considered statistically significant when $P<0.05$. The geometric mean ratio between the TTT and CGC homozygotes with $95 \%$ confidence interval (CI) was calculated for the $\mathrm{C}_{\max }$, AUC, Ae, and $\mathrm{Cl}_{\text {renal }}$ values, and the mean difference with $95 \% \mathrm{CI}$ for the $\mathrm{t}_{1 / 2}$ and renin activity variables. The number of subjects was estimated to be sufficient to detect a $50 \%$ difference in the $\mathrm{AUC}_{0-\infty}$ of aliskiren between the $A B C B 1$ CGC and TTT homozygotes, with a power of $80 \%(\alpha-$ level $5 \%)$. 


\section{RESULTS}

$A B C B 1$ haplotypes had no significant effect on the pharmacokinetics or renin-inhibiting effect of aliskiren (Table 1, Fig. 1). The geometric mean ratio (95\% CI) of aliskiren $\mathrm{C}_{\max }$ and $\mathrm{AUC}_{0-\infty}$ in participants homozygous for the TTT haplotype to those in participants homozygous for the CGC haplotype were $1.14(0.66,1.96 ; P=0.631)$ and $1.01(0.58,1.76 ; P=0.960)$, respectively. As a post hoc analysis, fractional AUC values $\left(\mathrm{AUC}_{0-1}, \mathrm{AUC}_{0-2}, \mathrm{AUC}_{0-3}, \mathrm{AUC}_{0-4}\right.$, and $\left.\mathrm{AUC}_{0-5}\right)$ were also calculated for aliskiren, but no tendency for a difference between the haplotype groups was observed in these values $\left(P>0.3\right.$, data not shown). Aliskiren $\mathrm{C}_{\max }, \mathrm{AUC}_{0-\infty}, \mathrm{Ae}$, and $\mathrm{Cl}_{\text {renal }}$ varied 14.1-, 16.2-, 10.4-, and 3.1-fold, respectively, between individual participants. 


\section{DISCUSSION}

In the present study, the $A B C B 1$ haplotypes had no significant effect on the pharmacokinetics or renin-inhibiting effect of the P-glycoprotein substrate aliskiren. However, these genetic results do not indicate that the P-glycoprotein transporter could not be otherwise important for the pharmacokinetics of aliskiren. In vitro, aliskiren is a high affinity substrate of P-glycoprotein $\left(\mathrm{K}_{\mathrm{m}} 2.1 \mu \mathrm{mol} / \mathrm{l}\right)$, as evidenced by studies in Pglycoprotein-expressing Sf9 cell membrane vesicles [2]. In vivo, inhibitors and inducers of P-glycoprotein markedly affect aliskiren pharmacokinetics [10, 11, 14].

It is noteworthy that $A B C B 1$ genotypes have explained only a fraction of the variability in P-glycoprotein expression, and the effects of $A B C B 1$ genotypes and haplotypes on drug pharmacokinetics have been modest $[15,17,28,29]$. For example, the AUCs of simvastatin acid and atorvastatin have been $60 \%$ and 55\% larger, respectively, in subjects homozygous for the $A B C B 1$ TTT haplotype compared with subjects homozygous for the CGC haplotype [17]. Studies investigating the effects of the $A B C B 1$ c. $3435 \mathrm{C}>\mathrm{T}$ SNP on the pharmacokinetics of the P-glycoprotein prototype substrate digoxin have revealed conflicting results, with a meta-analysis suggesting that the $A B C B 1$ c.3435C $>$ T SNP does not affect digoxin pharmacokinetics [12, 15, 28-31]. It has been suggested that the $A B C B 1$ c. $3435 \mathrm{C}>\mathrm{T} \mathrm{SNP}$, or its combination with the c. $1236 \mathrm{C}>\mathrm{T}$ or c. $2677 \mathrm{G}>\mathrm{T} / \mathrm{A}$ SNP, may alter the substrate specificity of P-glycoprotein [16]. Therefore, the effect of the $A B C B 1$ genotype on the pharmacokinetics of different P-glycoprotein substrates may vary. 
The present study had sufficient power to detect a $50 \%$ difference in the $\mathrm{AUC}_{0-\infty}$ of aliskiren between $A B C B 1$ haplotypes, and thus a small difference cannot be ruled out. However, it is unlikely that a smaller than $50 \%$ difference in aliskiren $\mathrm{AUC}_{0-\infty}$ would be of clinical importance. For example, a 76\% increase in aliskiren AUC by ketoconazole was not considered clinically relevant [2]. Nevertheless, the mean $\mathrm{AUC}_{0-\infty}$ values of aliskiren were almost identical in the two haplotype groups.

Similarly to previous reports [25], a high interindividual variability was observed in the $\mathrm{C}_{\max }$ and $\mathrm{AUC}$ values of aliskiren. The present results suggest that common $A B C B 1$ haplotypes do not explain this variability. The large differences in aliskiren pharmacokinetics might be explained by variability in gastrointestinal physiology, and other genetic and non-genetic factors affecting the activity of P-glycoprotein or CYP3A, or other transporters or enzymes involved in aliskiren pharmacokinetics [2].

In conclusion, the common $A B C B 1$ haplotypes c. $1236 \mathrm{C}-\mathrm{c} .2677 \mathrm{G}-\mathrm{c} .3435 \mathrm{C}$ and c.1236Tc.2677T-c.3435T have no effects on the pharmacokinetics or pharmacodynamics of aliskiren. 


\section{ACKNOWLEDGEMENTS}

We thank Ms Kaisa Kurkinen, MSc, for aliskiren concentration measurements, and Ms Eija Mäkinen-Pulli, Ms Lisbet Partanen, and Mr Jouko Laitila for skilled assistance. This study was supported by grants from the Sigrid Jusélius Foundation (Helsinki, Finland).

\section{COMPETING INTEREST}

None to declare. 


\section{References}

1 Waldmeier F, Glaenzel U, Wirz B, Oberer L, Schmid D, Seiberling M, Valencia J, Riviere GJ, End P, Vaidyanathan S (2007) Absorption, distribution, metabolism, and elimination of the direct renin inhibitor aliskiren in healthy volunteers. Drug Metab Dispos 35 (8): 1418-1428

2 Vaidyanathan S, Camenisch G, Schuetz H, Reynolds C, Yeh CM, Bizot MN, Dieterich HA, Howard D, Dole WP (2008) Pharmacokinetics of the oral direct renin inhibitor aliskiren in combination with digoxin, atorvastatin, and ketoconazole in healthy subjects: the role of P-glycoprotein in the disposition of aliskiren. J Clin Pharmacol 48 (11): 1323-1338

3 Fromm MF (2004) Importance of P-glycoprotein at blood-tissue barriers. Trends Pharmacol Sci 25 (8): 423-429 Dahlin A, Evers R, Fischer V, Hillgren KM, Hoffmaster KA, Ishikawa T, Keppler D, Kim RB, Lee CA, Niemi M, Polli JW, Sugiyama Y, Swaan PW, Ware JA, Wright SH, Wah Yee S, Zamek-Gliszczynski MJ, Zhang L (2010) Membrane transporters in drug development. Nat Rev Drug Discov 9 (3): 215-236

5 Olkkola KT, Backman JT, Neuvonen PJ (1994) Midazolam should be avoided in patients receiving the systemic antimycotics ketoconazole or itraconazole. Clin Pharmacol Ther 55 (5): 481-485 
Jalava KM, Partanen J, Neuvonen PJ (1997) Itraconazole decreases renal clearance of digoxin. Ther Drug Monit 19 (6): 609-613

Interaction of common azole antifungals with P glycoprotein. Antimicrob Agents Chemother 46 (1): 160-165

8 Rao US, Scarborough GA (1994) Direct demonstration of high affinity interactions of immunosuppressant drugs with the drug binding site of the human Pglycoprotein. Mol Pharmacol 45 (4): 773-776

9

Kajosaari LI, Niemi M, Neuvonen M, Laitila J, Neuvonen PJ, Backman JT (2005) Cyclosporine markedly raises the plasma concentrations of repaglinide. Clin Pharmacol Ther 78 (4): 388-399

10 Tapaninen T, Backman JT, Kurkinen KJ, Neuvonen PJ, Niemi M (2010) Itraconazole, a P-glycoprotein and CYP3A4 inhibitor, markedly raises the plasma concentrations and enhances the renin-inhibiting effect of aliskiren. J Clin Pharmacol Doi:10.1177/0091270010365885 European Public Assessment Report for Rasilez. Available from URL:http://www.emea.europa.eu/humandocs/Humans/EPAR/rasilez/rasilez.htm. Accessed Mar 11, 2010 
Zundler J, Kroemer HK (1999) The role of intestinal P-glycoprotein in the interaction of digoxin and rifampin. J Clin Invest 104 (2): 147-153

13

Niemi M, Backman JT, Fromm MF, Neuvonen PJ, Kivistö KT (2003)

Pharmacokinetic interactions with rifampicin: clinical relevance. Clin Pharmacokinet 42 (9): $819-850$

14

Tapaninen T, Neuvonen PJ, Niemi M (2010) Rifampicin reduces the plasma concentrations and the renin-inhibiting effect of aliskiren. Eur J Clin Pharmacol 66 (5): 497-502

15

Hoffmeyer S, Burk O, von Richter O, Arnold HP, Brockmöller J, Johne A, Cascorbi I, Gerloff T, Roots I, Eichelbaum M, Brinkmann U (2000) Functional polymorphisms of the human multidrug-resistance gene: multiple sequence variations and correlation of one allele with P-glycoprotein expression and activity in vivo. Proc Natl Acad Sci U S A 97 (7): 3473-3478

16 Kimchi-Sarfaty C, Oh JM, Kim IW, Sauna ZE, Calcagno AM, Ambudkar SV, Gottesman MM (2007) A "silent" polymorphism in the MDR1 gene changes substrate specificity. Science 315 (5811): 525-528 haplotypes differentially affect the pharmacokinetics of the acid and lactone forms of simvastatin and atorvastatin. Clin Pharmacol Ther 84 (4): 457-461 
resistance polypeptide 1 (MDR1, ABCB1) variant 3435C $>$ T affects mRNA stability. Pharmacogenet Genomics 15 (10): 693-704 GR (2001) Identification of functionally variant MDR1 alleles among European Americans and African Americans. Clin Pharmacol Ther 70 (2): 189-199 Giacomini KM, Clark AG (2003) Sequence diversity and haplotype structure in the human ABCB1 (MDR1, multidrug resistance transporter) gene. Pharmacogenetics 13 (8): 481-494 nucleotide polymorphisms in the P-glycoprotein drug transporter MDR1 gene in white subjects. Clin Pharmacol Ther 69 (3): 169-174 genotype and PGP expression, function and therapeutic drug response: a critical review and recommendations for future research. Pharmacogenomics J 7 (3): 154-179 
Polymorphisms in the multidrug resistance-1 (MDR1) gene influence the response to atorvastatin treatment in a gender-specific manner. Am J Cardiol 93 (8): 1046-1050

Ferreira ME, Pires RC, Hutz MH (2005) The role of common variants of ABCB1, CYP3A4, and CYP3A5 genes in lipid-lowering efficacy and safety of simvastatin treatment. Clin Pharmacol Ther 78 (5): 551-558

Clinical pharmacokinetics and pharmacodynamics of aliskiren. Clin Pharmacokinet 47 (8): $515-531$

Schwab M, Eichelbaum M, Strandberg T (2004) Lipid-lowering response to statins is affected by CYP3A5 polymorphism. Pharmacogenetics 14 (8): 523-525

Influence of body weight and gender on the pharmacokinetics, pharmacodynamics, and antihypertensive efficacy of aliskiren. J Clin Pharmacol

Doi:10.1177/0091270009359525 Funck-Brentano C, Becquemont L (2003) Digoxin pharmacokinetics and MDR1 genetic polymorphisms. Eur J Clin Pharmacol 58 (12): 809-812 
Johne A, Köpke K, Gerloff T, Mai I, Rietbrock S, Meisel C, Hoffmeyer S, Kerb R, Fromm MF, Brinkmann U, Eichelbaum M, Brockmöller J, Cascorbi I, Roots I (2002) Modulation of steady-state kinetics of digoxin by haplotypes of the Pglycoprotein MDR1 gene. Clin Pharmacol Ther 72 (5): 584-594

T, Morita Y, Tamura T, Aoyama N, Hirai M, Kasuga M, Okumura K (2001) MDR1 genotype-related pharmacokinetics of digoxin after single oral administration in healthy Japanese subjects. Pharm Res 18 (10): 1400-1404

31

Chowbay B, Li H, David M, Cheung YB, Lee EJ (2005) Meta-analysis of the influence of MDR1 C3435T polymorphism on digoxin pharmacokinetics and MDR1 gene expression. Br J Clin Pharmacol 60 (2): 159-171 
Table 1 Pharmacokinetic variables of and plasma renin activity response to a single 150-mg oral dose of aliskiren in healthy subjects homozygous for the $A B C B 1$ c.1236C-c.2677G-c.3435C (CGC/CGC genotype; $n=11$ ) or c.1236T-c.2677T-c.3435T (TTT/TTT genotype; $n=11)$ haplotype

\begin{tabular}{|c|c|c|c|c|}
\hline \multirow[t]{2}{*}{ Variable } & \multicolumn{2}{|c|}{$A B C B 1$ genotype } & \multirow{2}{*}{$\begin{array}{c}\text { Geometric mean ratio } \\
(95 \% \mathrm{CI})\end{array}$} & \multirow[t]{2}{*}{$P$ value } \\
\hline & CGC/CGC & TTT/TTT & & \\
\hline \multicolumn{5}{|l|}{ Aliskiren } \\
\hline $\mathrm{C}_{\max }(\mathrm{ng} / \mathrm{ml})$ & $98(67,143)$ & $111(76,163)$ & $1.14(0.66,1.96)$ & 0.631 \\
\hline $\mathrm{t}_{\max }(\mathrm{h})$ & $1(0.5-5)$ & $0.5(0.5-5)$ & & 0.495 \\
\hline $\mathrm{t}_{1 / 2}(\mathrm{~h})$ & $23.9(19.0,28.8)$ & $22.5(17.6,27.4)$ & $-1.4(-8.3,5.5)^{*}$ & 0.684 \\
\hline $\mathrm{AUC}_{0-72}(\mathrm{ng} \cdot \mathrm{h} / \mathrm{ml})$ & $419(289,608)$ & $429(296,622)$ & $1.02(0.60,1.74)$ & 0.927 \\
\hline $\mathrm{AUC}_{0-\infty}(\mathrm{ng} \cdot \mathrm{h} / \mathrm{ml})$ & $443(301,652)$ & $449(306,661)$ & $1.01(0.58,1.76)$ & 0.960 \\
\hline $\mathrm{Ae}(\mathrm{mg})$ & $0.499(0.335,0.742)$ & $0.516(0.347,0.767)$ & $1.03(0.58,1.83)$ & 0.905 \\
\hline $\mathrm{Cl}_{\text {renal }}(\mathrm{l} / \mathrm{h})$ & $1.75(1.48,2.06)$ & $1.71(1.45,2.01)$ & $0.98(0.77,1.23)$ & 0.842 \\
\hline \multicolumn{5}{|c|}{ Plasma renin activity $(\mathrm{ng} / \mathrm{ml} / \mathrm{h})$} \\
\hline At baseline & $1.73(0.96,2.50)$ & $2.38(1.61,3.15)$ & $0.66(-0.43,1.75)^{*}$ & 0.222 \\
\hline At $4 \mathrm{~h}$ & $0.01(-0.09,0.11)$ & $0.09(-0.01,0.19)$ & $0.08(-0.06,0.22)^{*}$ & 0.251 \\
\hline At $24 \mathrm{~h}$ & $1.08(0.51,1.65)$ & $1.36(0.79,1.92)$ & $0.28(-0.52,1.08)^{*}$ & 0.479 \\
\hline
\end{tabular}

$\mathrm{C}_{\max }, \mathrm{AUC}$, and Ae data are estimated marginal mean $(95 \% \mathrm{CI})$ adjusting for weight; $\mathrm{t}_{1 / 2}, \mathrm{Cl}_{\mathrm{renal}}$, and plasma renin activity are estimated marginal mean $(95 \% \mathrm{CI}) ; \mathrm{t}_{\max }$ are median (range). CI, Confidence interval; $\mathrm{C}_{\max }$, peak plasma concentration; $\mathrm{t}_{\max }$, time to $\mathrm{C}_{\max } ; \mathrm{t}_{1 / 2}$, elimination half-life; $\mathrm{AUC}_{0-72}$, area under the plasma concentration-time curve from 0 to $72 \mathrm{~h} ; \mathrm{AUC}_{0-\infty}$, area under the plasma concentration-time curve from time 0 to infinity; Ae, amount excreted into urine within $12 \mathrm{~h} ; \mathrm{Cl}_{\text {renal }}$ renal clearance; Baseline, before the administration of aliskiren.

* Mean difference $(95 \% \mathrm{CI})$. 


\section{FIGURE LEGEND}

Fig. 1 Weight-adjusted mean \pm SEM plasma concentrations of aliskiren (A) and mean \pm SEM plasma renin activity (B) after a single 150-mg oral dose of aliskiren in subjects homozygous for the $A B C B 1$ c.1236C-c.2677G-c.3435C ( $n=11$; open circles) or $A B C B 1$ c.1236T-c.2677T-c.3435T ( $n=11$; solid circles) haplotype. The inset in part A shows aliskiren plasma concentration data on a semi-logarithmic scale 


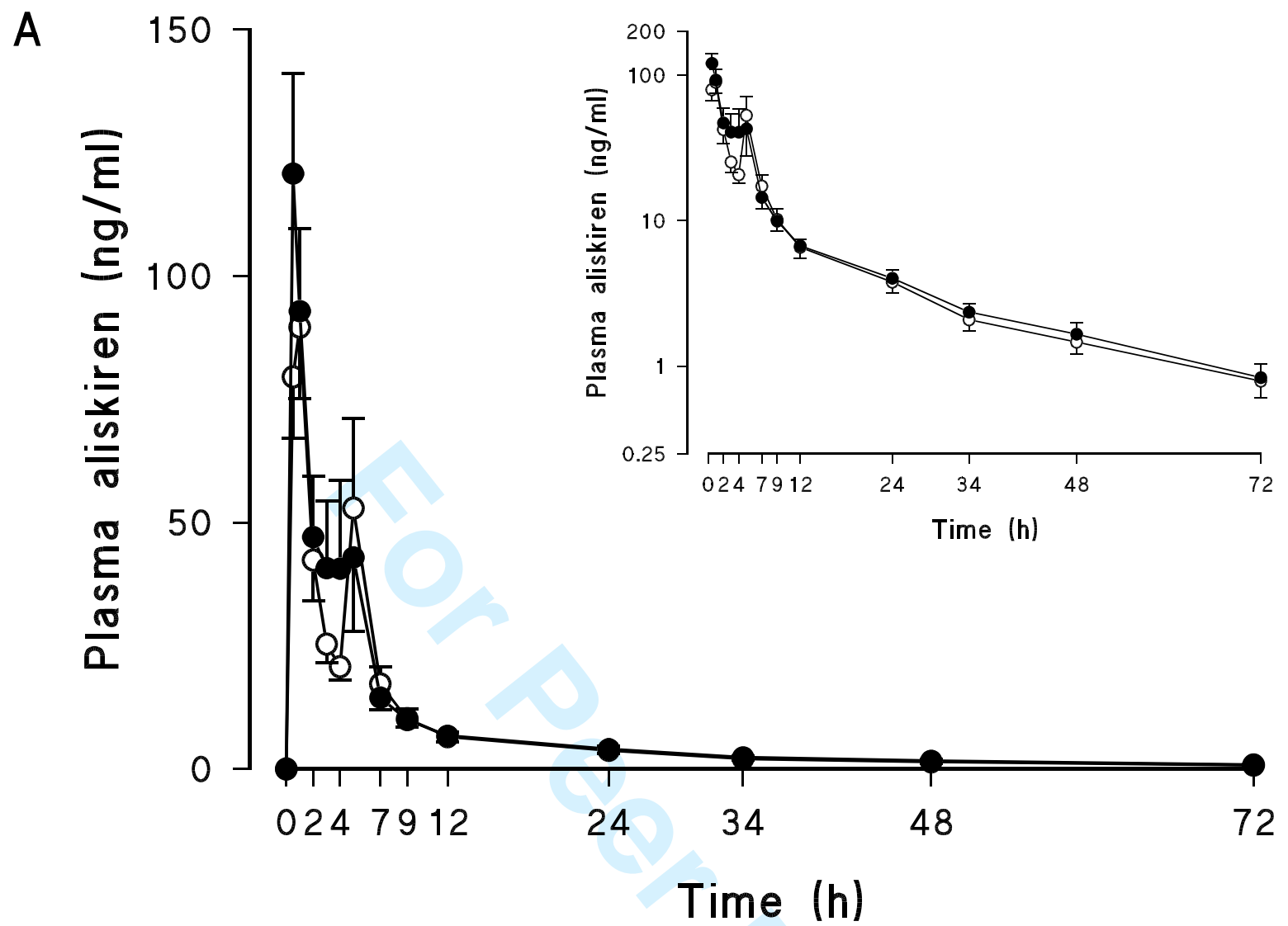

B

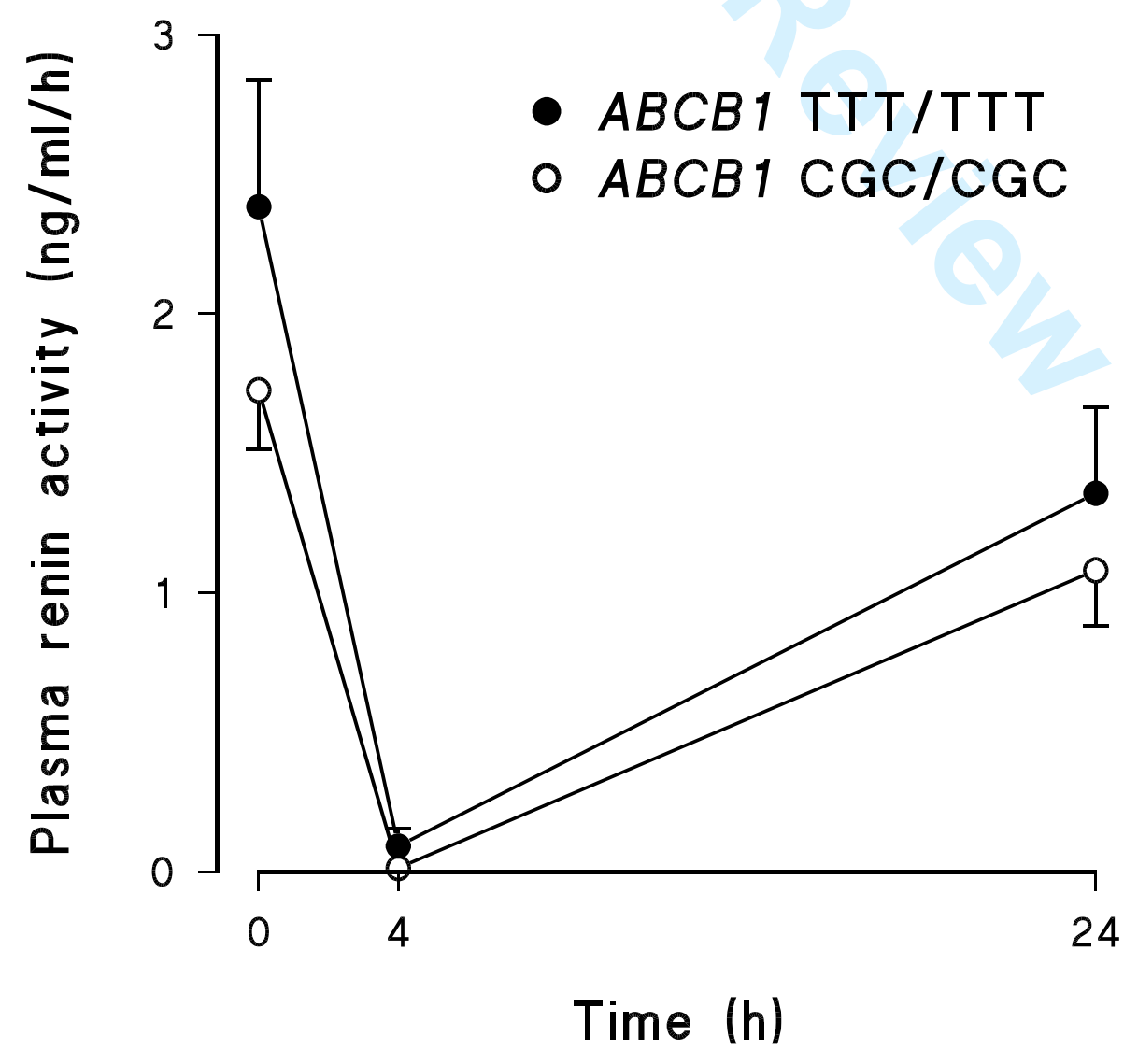


1

2

3

\section{Effect of $A B C B 1$ haplotypes on the pharmacokinetics and} renin-inhibiting effect of aliskiren

Tuija Tapaninen, Pertti J. Neuvonen and Mikko Niemi

Department of Clinical Pharmacology, University of Helsinki and Helsinki University Central Hospital, Helsinki, Finland

Correspondence and requests for reprints:

Mikko Niemi, MD

Department of Clinical Pharmacology,

Helsinki University Central Hospital

PO Box 705, FI-00029 HUS, Finland

Fax: +358-9-471 74039

E-mail: mikko.niemi@helsinki.fi

Word count: 2153 words (excluding the title page, summary, references, tables, and

Deleted: 1540 figures)

A revised manuscript (EJCP 2010-0093) for European Journal of Clinical 


\begin{abstract}
Purpose

This study aimed to investigate possible effects of $A B C B 1$ haplotypes on the pharmacokinetics and renin-inhibiting effect of aliskiren.
\end{abstract}

\section{Methods}

Eleven healthy volunteers homozygous for the $A B C B 1$ c.1236C-c.2677G-c.3435C (CGC) haplotype and eleven homozygous for the c.1236T-c.2677T-c.3435T, (TTT) haplotype ingested a single 150-mg dose of aliskiren. Plasma aliskiren concentrations were measured up to $72 \mathrm{~h}$, its excretion into urine up to $12 \mathrm{~h}$, and plasma renin activity up to $24 \mathrm{~h}$.

\section{Results}

The $A B C B 1$ haplotypes had no significant effect on the pharmacokinetics or renininhibiting effect of aliskiren. The geometric mean ratio (95\% confidence interval) of aliskiren peak plasma concentration and area under the plasma concentration-time curve from $0 \mathrm{~h}$ to infinity in participants homozygous for the TTT haplotype to those in participants homozygous for the CGC haplotype were $1.14(0.66,1.96 ; P=0.631)$ and $1.01(0.58,1.76 ; P=0.960)$, respectively.

\section{Conclusions}

These data suggest that the $A B C B 1$ c.1236C-c.2677G-c.3435C and c.1236T-c.2677T-

c.3435T haplotypes have no clinically meaningful effect on the pharmacokinetics of aliskiren.

\section{KEYWORDS}

Pharmacokinetics, Pharmacogenetics, $A B C B 1$ haplotypes, Aliskiren
Deleted: genotype

\begin{tabular}{l} 
Deleted: with \\
Deleted: /C \\
Deleted: /G \\
Deleted: /C \\
Deleted: /CGC \\
Deleted: genotype \\
Deleted: with \\
Deleted: /T \\
Deleted: /T $/ T$ \\
Deleted: $/ T T T$ \\
Deleted: genotype \\
\hline
\end{tabular}

Deleted: with

Deleted: /TTT

Deleted: genotype

Deleted: with

Deleted: /CGC

Deleted: genotype 
INTRODUCTION

The direct renin inhibitor aliskiren is poorly absorbed and has a low oral bioavailability of 2-3\% [1]. Aliskiren is mainly eliminated by biliary excretion [1]. In addition, about $0.4 \%$ of the oral dose is excreted unchanged into urine and about $1.4 \%$ undergoes oxidative biotransformation via CYP3A4 [1]. Aliskiren is a substrate of P-glycoprotein (also known as ABCB1) [2], an efflux transporter expressed in tissues with an excretory or barrier function $[3,4]$. The P-glycoprotein and CYP3A4 inhibitors, itraconazole and cyclosporine [5-9], have raised the area under the plasma concentration-time curve (AUC) of aliskiren by about 6.5-fold and 5-fold, respectively [10, 11], supporting a major role of P-glycoprotein in limiting the intestinal absorption of aliskiren. Moreover, rifampicin, an inducer of P-glycoprotein and CYP3A4 [12, 13], has reduced the AUC of aliskiren by $56 \%$ [14].

A common synonymous single nucleotide polymorphism (SNP) in the $A B C B 1$ gene encoding P-glycoprotein, c.3435C $>\mathrm{T}$, has been variably associated with reduced expression and function of P-glycoprotein in vitro and increased plasma concentrations of P-glycoprotein substrate drugs in vivo [15-17]. The mechanism underlying these associations is not completely understood, but it has been suggested that c.3435C $>\mathrm{T}$ affects $A B C B 1$ mRNA stability [18]. Alternatively, the associations may be explained by linkage disequilibrium between c. $3435 \mathrm{C}>\mathrm{T}$ and a functional sequence variation, or that $\mathrm{c} .3435 \mathrm{C}>\mathrm{T}$ and sequence variations in linkage disequilibrium with it form a haplotype conferring altered P-glycoprotein activity [16, 19]. The $A B C B 1 \mathrm{c} .3435 \mathrm{C}>\mathrm{T}$

Deleted: ABCB1 (also known as Pglycoprotein) is an efflux transporter expressed in tissues with an excretory or barrier function $[1,2]$.

Deleted: $\mathrm{ABCB} 1$

\begin{tabular}{l} 
Deleted: $\mathrm{ABCB} 1$ \\
\hline Deleted: 3 \\
\hline Deleted: 5 \\
\hline
\end{tabular}


$\mathrm{SNP}$ is in strong linkage disequilibrium with the c.1236C $>\mathrm{T}$ (synonymous) and

c. $2677 \mathrm{G}>\mathrm{T} / \mathrm{A}$ (p.Ala893Ser/Thr) SNPs within the same gene $[17,19,20]$.

The variant alleles c.1236T, c.2677T, and c.3435T are common in Europeans and

European Americans, with reported frequencies of occurrence ranging from 39 to $46 \%$,

39 to $47 \%$, and 54 to $60 \%$, respectively [17, 19-22]. In the Finnish population, the two most common haplotypes based on these SNPs are c.1236T-c.2677T-c.3435T (TTT)

\begin{tabular}{|l|}
\hline Deleted: 5 \\
\hline Deleted: 7 \\
\hline Deleted: 10
\end{tabular}
and c.1236C-c.2677G-c.3435C (CGC), with frequencies of $42.7 \%$ and $34.4 \%$,

respectively [17]. The $A B C B 1$ TTT haplotype has been associated, for example, with

Deleted: 5 increased plasma concentrations of and enhanced lipid-lowering response to simvastatin (acid) and atorvastatin, compared with the $A B C B 1$ CGC haplotype $[17,23,24]$.

Considerable interindividual variability exists in the pharmacokinetics of aliskiren [25], but the background of this variability is unknown. Our hypothesis was that genetic variability in $A B C B 1$ affects the pharmacokinetics of aliskiren. Therefore, we investigated the effects of the $A B C B 1 C G C$ and TTT haplotypes on the pharmacokinetics and pharmacodynamics of aliskiren.

\begin{tabular}{l} 
Deleted: 5 \\
\hline Deleted: 11 \\
\hline Deleted: 12 \\
Deleted: The antihypertensive drug \\
aliskiren is a substrate of ABCB1 [13]. It \\
is poorly absorbed and has a low oral \\
bioavailability of 2-3\% [14]. Aliskiren is \\
mainly eliminated by biliary excretion \\
[14]. In addition, about 0.4\% of the oral \\
dose is excreted unchanged into urine and \\
about $1.4 \%$ undergoes oxidative \\
biotransformation via CYP3A4 [14]. The \\
ABCB1 and CYP3A4 inhibitors, \\
itraconazole and cyclosporine [15-19], \\
have raised the AUC of aliskiren by about \\
6.5 -fold and 5-fold, respectively [20, 21], \\
supporting a major role of ABCB1 in \\
limiting the intestinal absorption of \\
aliskiren. Moreover, rifampicin, an \\
inducer of ABCB1 and CYP3A4 [22, 23], \\
has reduced the AUC of aliskiren by 56\% \\
[24].I \\
II \\
Deleted: /CGC \\
Deleted: /TTT \\
Deleted: genotypes \\
\hline
\end{tabular}




\section{METHODS}

\section{Subjects}

Twenty-two healthy White Finnish volunteers participated in this study after giving written informed consent. They were recruited from a group of more than 700 subjects genotyped for the $A B C B 1$ c.1236C $>\mathrm{T}$ (rs1128503), c.2677G $>\mathrm{T} / \mathrm{A}$ (rs2032582), and c.3435C > T (rs1045642) SNPs [17]. To minimize variability in aliskiren

Deleted: 5 pharmacokinetics due to other genetic variants, all subjects were genotyped for the functionally significant $A B C B 1$ c.1199G $>A$ (p.Ser400Asn; rs2229109) [17] and $C Y P 3 A 5 * 3$ (g.6986A $>\mathrm{G} ;$ rs776746) [26] alleles and only noncarriers of the $A B C B 1$ c.1199A and CYP3A5 g.6986A (CYP3A5 expressor) alleles were recruited, Deleted: [5]

Four women and seven men homozygous for the $A B C B 1$ CGC haplotype, mean \pm SD age $26 \pm 4$ years (range, $22-37$ years), height $178 \pm 9 \mathrm{~cm} \underline{(158-189 \mathrm{~cm})}$, and weight $74 \pm$ $11 \mathrm{~kg}(63-95 \mathrm{~kg})_{2}$ and five women and six men homozygous for the TTT, haplotype, age $24 \pm 2$ years $\underline{(21-27 \text { years })}$, height $175 \pm 10 \mathrm{~cm} \underline{(158-186 \mathrm{~cm})}$, and weight $69 \pm 12 \mathrm{~kg}$ $(51-94 \mathrm{~kg})_{2}$ participated in the study. Each participant's health was ascertained by medical history, clinical examination, and laboratory tests. None was on any continuous medication and none was a tobacco smoker.

\section{Study design}

The study protocol was approved by the Coordinating Ethics Committee of the Helsinki and Uusimaa Hospital District, and the National Agency for Medicines. Following an overnight fast, the subjects ingested a single 150-mg dose of aliskiren (Rasilez; 
Novartis, Horsham, UK) with $150 \mathrm{ml}$ water. A standardized warm meal was served $4 \mathrm{~h}$ after aliskiren, and a standardized light meal after $7 \mathrm{~h}$ and $10 \mathrm{~h}$. As a safety assessment, systolic and diastolic blood pressures were measured from the forearm with an automatic oscillometric blood pressure monitor (Omron M5-I, Omron Healthcare Europe BV, Hoofddorp, The Netherlands), with the participant in a sitting position, prior to and $2,4,7,9,12$, and $24 \mathrm{~h}$ after aliskiren ingestion. The participants were under direct medical supervision for $12 \mathrm{~h}$ after the administration of aliskiren. No significant differences in blood pressures were observed between the haplotype groups (data not shown). Use of other drugs was prohibited for one week and use of grapefruit products for three days before aliskiren administration and $72 \mathrm{~h}$ thereafter.

Timed blood samples ( 5 or $10 \mathrm{ml}$ each) for aliskiren concentration measurements were drawn into tubes containing ethylenediaminetetraacetic acid (EDTA) prior to and $0.5,1$, $\underline{2,3,4,5,7,9,12,24,34,48 \text {, and } 72 \mathrm{~h} \text { after aliskiren administration. Blood samples for }}$ Deleted: Timed ethylenediaminetetraacetic acid blood samples (5-15 ml each) were drawn prior to and up to $72 \mathrm{~h}$ after aliskiren ingestion. Plasma was separated within $30 \mathrm{~min}$. Urine was collected up to $12 \mathrm{~h}$ after aliskiren ingestion. The samples were stored at $-70^{\circ} \mathrm{C}$ until analysis. II the determination of plasma renin activity $(5 \mathrm{ml}$ each $)$ were drawn before the administration of aliskiren and $4 \mathrm{~h}$ and $24 \mathrm{~h}$ thereafter into chilled EDTA tubes, which were placed on ice immediately after sampling. Plasma was separated within $30 \mathrm{~min}$. Urine was collected up to $12 \mathrm{~h}$ after aliskiren ingestion. Urine aliquots and plasma were stored at $-70^{\circ} \mathrm{C}$ until analysis.

\section{Determination of aliskiren concentrations and renin activity}

Plasma concentrations of aliskiren were quantified by use of solid phase extraction and liquid chromatography-tandem mass spectrometry (LC/MS/MS) [10]. An aliquot of 700 $\mu \mathrm{l}$ of each plasma sample was mixed with $100 \mu \mathrm{l}$ of $10 \%$ phosphoric acid and $50 \mu \mathrm{l}$ 
internal standard solution (1000 ng/ml acebutolol in 1:1 methanol:water). Then the mixture was loaded to the extraction cartridge (Oasis MCX 1cc/30 mg, Waters, Milford, MA, USA), which had been pre-conditioned with $1 \mathrm{ml}$ of methanol and $1 \mathrm{ml}$ of $1 \%$ acetic acid. The cartridge was subsequently washed with $1 \mathrm{ml}$ of methanol and $1 \mathrm{ml}$ of $1 \%$ acetic acid. The analytes were eluted out with two times $0.6 \mathrm{ml}$ of $2 \%$ ammonium hydroxide in methanol. The eluent was dried at $50^{\circ} \mathrm{C}$ under a nitrogen stream. The residue was dissolved in $100 \mu \mathrm{l}$ of the mobile phase, and $15 \mu \mathrm{l}$ of the sample was injected to the LC/MS/MS system. The chromatographic separation was carried out on an AtlantisT3 column $(2.1 \times 100 \mathrm{~mm}, 3 \mu \mathrm{m})$ protected by an AtlantisT3 $(2.1 \times 10 \mathrm{~mm}, 3$ $\underline{\mu m}$ ) guard cartridge (Waters). The mobile phase consisted of (A) $2 \mathrm{mmol} / \mathrm{l}$ ammonium acetate ( $\mathrm{pH} 4.90)$ and (B) methanol. The total running time was 15 minutes with the mobile phase gradient of 0.5 minutes at $70 \% \mathrm{~A}, 0.5$ minutes to $5 \% \mathrm{~A}, 3$ minutes at $5 \%$ A, 0.1 minutes to $70 \% \mathrm{~A}$, and 10.9 minutes at $70 \% \mathrm{~A}$. The flow rate of the mobile phase was $250 \mu \mathrm{l} / \mathrm{min}$. The column temperature was $40^{\circ} \mathrm{C}$. Mass spectra were obtained using an Applied Biosystems SCIEX API 2000 Q Trap mass spectrometer operated in positive ion mode (Sciex Division of MDS Inc, Toronto, ON, Canada). The ion transitions were mass-to-charge ratio (m/z) 552.4 to $\mathrm{m} / \mathrm{z} 436.3$ for aliskiren and m/z $\underline{337.3 \text { to } \mathrm{m} / \mathrm{z} 116.3 \text { for acebutolol. }}$

For the determination of aliskiren concentrations in urine, an aliquot of $300 \mu \mathrm{l}$ of each urine sample was mixed with $300 \mu \mathrm{l}$ of fresh frozen plasma, $100 \mu \mathrm{l}$ of $10 \%$ phosphoric acid, and $50 \mu \mathrm{l}$ internal standard solution $(1000 \mathrm{ng} / \mathrm{ml}$ acebutolol in 1:1 methanol:water). The extraction, chromatographic separation, and mass spectrometric detection were performed as described for plasma aliskiren ${ }_{\checkmark}$ The lower limit of

Deleted: Aliskiren plasma and urine concentrations were quantified using an Applied Biosystems SCIEX Q Trap LC/MS/MS system (Sciex Division of MDS, Toronto, ON, Canada) [20]. Acebutolol served as an internal standard. 
quantification was $0.25 \mathrm{ng} / \mathrm{ml}$ for plasma and $9 \mathrm{ng} / \mathrm{ml}$ for urine aliskiren. The calibration curve for plasma aliskiren was linear over the range $0.25-500 \mathrm{ng} / \mathrm{ml}$ $\underline{(r>0.999, \text { weighting } 1 / x) \text { and for urine aliskiren over the range } 9-1800 \mathrm{ng} / \mathrm{ml}(\mathrm{r}>0.999 \text {, }}$ weighting $1 / x)$. The extraction recoveries were $>80 \%$. The intra-day coefficients of variation were $\leq 1.2 \%$ at relevant concentrations in plasma and $\leq 4.8 \%$ in urine $(n=6)$.

Plasma renin activity was determined by radioimmunoassay of generated angiotensin I with a commercially available method (RENCTK; DiaSorin, Saluggia, Italy) at HUSLAB laboratory (Helsinki, Finland).

\section{Pharmacokinetics and pharmacodynamics}

Aliskiren pharmacokinetics were characterized by peak plasma concentration $\left(\mathrm{C}_{\max }\right)$,

time to $\mathrm{C}_{\max }\left(\mathrm{t}_{\max }\right)$, elimination half-life $\left(\mathrm{t}_{1 / 2}\right)$, $\mathrm{AUC}_{0-72} \mathrm{AUC}_{0-\mathrm{x}_{e}}$ the amount of aliskiren excreted into urine from 0 to $12 \mathrm{~h}(\mathrm{Ae})$, and the renal clearance $\left(\mathrm{Cl}_{\text {renal }}\right)$.

Deleted: areas under the plasma concentration-time curve from 0 to $72 \mathrm{~h}$ ( Deleted: ) and $0 \mathrm{~h}$ to infinity ( Deleted: )

Pharmacokinetic parameters were calculated with non-compartmental methods using MK-Model, version 5.0 (Biosoft, Cambridge, UK). The terminal log-linear part of each concentration-time curve was identified visually. The elimination rate constant $\left(\mathrm{k}_{e}\right)$ was determined by linear regression analysis of the log-linear part of the plasma drug concentration-time curve. The $t_{1 / 2}$ was calculated by the equation $t_{1} / 2=\ln 2 / k_{e}$. The AUC values were calculated by a combination of the linear and log-linear trapezoidal rules with extrapolation to infinity, when appropriate, by division of the last measured concentration by $\mathrm{k}_{\mathrm{e}}$. The $\mathrm{Cl}_{\text {renal }}$ of aliskiren was calculated by the equation $\underline{\mathrm{Cl}}_{\underline{r e n a l}}=\mathrm{Ae} / \mathrm{AUC}_{0-12}$. Aliskiren pharmacodynamics were characterized by plasma renin activity at $4 \mathrm{~h}$ and $24 \mathrm{~h}$ after aliskiren intake. 


\section{Statistical analysis}

The data were analyzed using SPSS 17.0 (SPSS, Chicago, IL, USA). The $\mathrm{C}_{\max }$, AUC, Ae, and $\mathrm{Cl}_{\mathrm{renal}}$ data were logarithmically transformed before statistical analysis.

Statistical comparisons were made between the $A B C B 1$ haplotypes using analysis of variance (ANOVA). Body weight was set as a covariate for $\mathrm{C}_{\max }$, AUC, and Ae [27].

The $t_{\max }$ data were compared with the Mann-Whitney test. Differences were considered statistically significant when $P<0.05$. The geometric mean ratio between the $\mathrm{TTT}_{\mathrm{v}}$ and CGC homozygotes with $95 \%$ confidence interval (CI) was calculated for the $\mathrm{C}_{\max }$,

Deleted: /TTT Deleted: /CGC Deleted: groups

AUC, $\mathrm{Ae}$, and $\mathrm{Cl}_{\text {renal }}$ values, and the mean difference with $95 \% \mathrm{CI}$ for the $\mathrm{t}_{1 / 2}$ and renin activity variables. The number of subjects was estimated to be sufficient to detect a $50 \%$ difference in the $\mathrm{AUC}_{0-\infty}$ of aliskiren between the $A B C B 1 \mathrm{CGC}_{\varepsilon}$ and TTT homozygotes, with a power of $80 \%(\alpha$-level 5\%).

\begin{tabular}{|l|}
\hline Deleted: /CGC \\
\hline Deleted: /TTT \\
\hline Deleted: groups \\
\hline
\end{tabular}




\section{RESULTS}

$A B C B 1$ haplotypes had no significant effect on the pharmacokinetics or renin-inhibiting

Deleted: genotype effect of aliskiren (Table 1, Fig. 1). The geometric mean ratio (95\% CI) of aliskiren

$\mathrm{C}_{\max }$ and $\mathrm{AUC}_{0-\infty}$ in participants homozygous for the TTT haplotype to those in participants homozygous for the CGC haplotype were $1.14(0.66,1.96 ; P=0.631)$ and $1.01(0.58,1.76 ; P=0.960)$, respectively. As a post hoc analysis, fractional AUC values $\left(\mathrm{AUC}_{0-1}, \mathrm{AUC}_{0-2}, \mathrm{AUC}_{0-3}, \mathrm{AUC}_{0-4}\right.$, and $\left.\mathrm{AUC}_{0-5}\right)$ were also calculated for aliskiren, but no tendency for a difference between the haplotype groups was observed in these values

Deleted: with Deleted: /TTT Deleted: genotype

Deleted: with

Deleted: /CGC

Deleted: genotype

Deleted: genotype $\left(P>0.3\right.$, data not shown). Aliskiren $\mathrm{C}_{\max }, \mathrm{AUC}_{0-\infty}, \mathrm{Ae}$, and $\mathrm{Cl}_{\text {renal }}$ varied 14.1-, 16.2-, 10.4-, and 3.1-fold, respectively, between individual participants. 
In the present study, the $A B C B 1$ haplotypes had no significant effect on the pharmacokinetics or renin-inhibiting effect of the P-glycoprotein substrate aliskiren. However, these genetic results do not indicate that the P-glycoprotein transporter could not be otherwise important for the pharmacokinetics of aliskiren. In vitro, aliskiren is a high affinity substrate of P-glycoprotein $\left(K_{m} 2.1 \mu \mathrm{mol} / \mathrm{l}\right)$, as evidenced by studies in Pglycoprotein-expressing Sf9 cell membrane vesicles [2]. In vivo, inhibitors and inducers of P-glycoprotein markedly affect aliskiren pharmacokinetics $[10,11,14]$.

It is noteworthy that $A B C B 1$ genotypes have explained only a fraction of the variability

in P-glycoprotein expression, and the effects of $A B C B 1$ genotypes and haplotypes on drug pharmacokinetics have been modest $[15,17,28,29]$. For example, the AUCs of simvastatin acid and atorvastatin have been $60 \%$ and $55 \%$ larger, respectively, in subjects homozygous for the $A B C B 1$ TTT haplotype compared with subjects homozygous for the CGChaplotype [17]. Studies investigating the effects of the $A B C B 1$ c. $3435 \mathrm{C}>\mathrm{T}$ SNP on the pharmacokinetics of the P-glycoprotein prototype substrate digoxin have revealed conflicting results, with a meta-analysis suggesting that the $A B C B 1$ c. $3435 \mathrm{C}>\mathrm{T}$ SNP does not affect digoxin pharmacokinetics [12, 15, 28-31]. It has been suggested that the $A B C B 1$ c. $3435 \mathrm{C}>\mathrm{T} \mathrm{SNP}$, or its combination with the c. $1236 \mathrm{C}>\mathrm{T}$ or c. $2677 \mathrm{G}>\mathrm{T} / \mathrm{A}$ SNP, may alter the substrate specificity of P-glycoprotein [16]. Therefore, the effect of the $A B C B 1$ genotype on the pharmacokinetics of different P-glycoprotein substrates may vary.
Deleted: genotype

Deleted: $\mathrm{ABCB} 1$

Deleted: $\mathrm{ABCB}$

\begin{tabular}{|l|}
\hline Deleted: with \\
\hline Deleted: /TTT \\
\hline Deleted: genotype \\
Deleted: with \\
Deleted: /CGC \\
Deleted: genotype \\
Deleted: 5 \\
\hline Deleted: ABCB1 \\
Deleted: 3 \\
\hline Deleted: 22 \\
\hline
\end{tabular}

Deleted: $A B C B 1$

Deleted: 4

Deleted: $\mathrm{ABCB} 1$ 
The present study had sufficient power to detect a $50 \%$ difference in the $\mathrm{AUC}_{0-\infty}$ of aliskiren between $A B C B 1$ haplotypes, and thus a small difference cannot be ruled out.

Similarly to previous reports [25], a high interindividual variability was observed in the

$\mathrm{C}_{\max }$ and AUC values of aliskiren. The present results suggest that common $A B C B 1$ haplotypes do not explain this variability. The large differences in aliskiren pharmacokinetics might be explained by variability in gastrointestinal physiology, and other genetic and non-genetic factors affecting the activity of P-glycoprotein or CYP3A, or other transporters or enzymes involved in aliskiren pharmacokinetics [2].

Deleted: $\mathrm{ABCB} 1$

In conclusion, the common $A B C B 1$ haplotypes c.1236C-c.2677G-c.3435C and c.1236T-

c.2677T-c.3435T have no effects on the pharmacokinetics or pharmacodynamics of aliskiren. 


\section{ACKNOWLEDGEMENTS}

We thank Ms Kaisa Kurkinen, MSc, for aliskiren concentration measurements, and Ms

Eija Mäkinen-Pulli, Ms Lisbet Partanen, and Mr Jouko Laitila for skilled assistance.

This study was supported by grants from the Sigrid Jusélius Foundation (Helsinki,

Finland).

\section{COMPETING INTEREST}

None to declare. 


\section{References}

1 Waldmeier F, Glaenzel U, Wirz B, Oberer L, Schmid D, Seiberling M,

Valencia J, Riviere GJ, End P, Vaidyanathan S (2007) Absorption, distribution,

metabolism, and elimination of the direct renin inhibitor aliskiren in healthy volunteers.

Drug Metab Dispos 35 (8): 1418-1428

2 Vaidyanathan S, Camenisch G, Schuetz H, Reynolds C, Yeh CM, Bizot

MN, Dieterich HA, Howard D, Dole WP (2008) Pharmacokinetics of the oral direct $\underline{\text { renin inhibitor aliskiren in combination with digoxin, atorvastatin, and ketoconazole in }}$ healthy subjects: the role of P-glycoprotein in the disposition of aliskiren. J Clin

Pharmacol 48 (11): 1323-1338

3. Fromm MF (2004) Importance of P-glycoprotein at blood-tissue barriers.

4 Giacomini KM, Huang SM, Tweedie DJ, Benet LZ, Brouwer KL, Chu X,

Dahlin A, Evers R, Fischer V, Hillgren KM, Hoffmaster KA, Ishikawa T, Keppler D,

Kim RB, Lee CA, Niemi M, Polli JW, Sugiyama Y, Swaan PW, Ware JA, Wright SH,

Wah Yee S, Zamek-Gliszczynski MJ, Zhang L (2010) Membrane transporters in drug development. Nat Rev Drug Discov 9 (3): 215-236

$\underline{5}$ Olkkola KT, Backman JT, Neuvonen PJ (1994) Midazolam should be avoided in patients receiving the systemic antimycotics ketoconazole or itraconazole. Clin Pharmacol Ther 55 (5): 481-485 

Jalava KM, Partanen J, Neuvonen PJ (1997) Itraconazole decreases renal clearance of digoxin. Ther Drug Monit 19 (6): 609-613 Wang EJ, Lew K, Casciano CN, Clement RP, Johnson WW (2002)

Interaction of common azole antifungals with $\mathrm{P}$ glycoprotein. Antimicrob Agents

Chemother 46 (1): 160-165

$\underline{8}$ Rao US, Scarborough GA (1994) Direct demonstration of high affinity interactions of immunosuppressant drugs with the drug binding site of the human Pglycoprotein. Mol Pharmacol 45 (4): 773-776

9 Kajosaari LI, Niemi M, Neuvonen M, Laitila J, Neuvonen PJ, Backman JT

(2005) Cyclosporine markedly raises the plasma concentrations of repaglinide. Clin Pharmacol Ther 78 (4): 388-399

10 Tapaninen T, Backman JT, Kurkinen KJ, Neuvonen PJ, Niemi M (2010)

Itraconazole, a P-glycoprotein and CYP3A4 inhibitor, markedly raises the plasma concentrations and enhances the renin-inhibiting effect of aliskiren. J Clin Pharmacol Doi:10.1177/0091270010365885

11 European Public Assessment Report for Rasilez. Available from

URL:http://www.emea.europa.eu/humandocs/Humans/EPAR/rasilez/rasilez.htm. Accessed Mar 11, 2010 
Greiner B, Eichelbaum M, Fritz P, Kreichgauer HP, von Richter O,

Zundler J, Kroemer HK (1999) The role of intestinal P-glycoprotein in the interaction of digoxin and rifampin. J Clin Invest 104 (2): 147-153

$\underline{13}$ Niemi M, Backman JT, Fromm MF, Neuvonen PJ, Kivistö KT (2003)

Pharmacokinetic interactions with rifampicin: clinical relevance. Clin Pharmacokinet 42 (9): $819-850$

14 Tapaninen T, Neuvonen PJ, Niemi M (2010) Rifampicin reduces the plasma concentrations and the renin-inhibiting effect of aliskiren. Eur J Clin Pharmacol $\underline{66(5): 497-502}$

$\underline{15}$ Hoffmeyer S, Burk O, von Richter O, Arnold HP, Brockmöller J, Johne A,

Cascorbi I, Gerloff T, Roots I, Eichelbaum M, Brinkmann U (2000) Functional polymorphisms of the human multidrug-resistance gene: multiple sequence variations and correlation of one allele with P-glycoprotein expression and activity in vivo. Proc Natl Acad Sci U S A 97 (7): 3473-3478

$\underline{16}$ Kimchi-Sarfaty C, Oh JM, Kim IW, Sauna ZE, Calcagno AM, Ambudkar SV, Gottesman MM (2007) A "silent" polymorphism in the MDR1 gene changes substrate specificity. Science 315 (5811): 525-528

17 Keskitalo JE, Kurkinen KJ, Neuvonen PJ, Niemi M (2008) ABCB1 haplotypes differentially affect the pharmacokinetics of the acid and lactone forms of simvastatin and atorvastatin. Clin Pharmacol Ther 84 (4): 457-461 
resistance polypeptide 1 (MDR1, ABCB1) variant $3435 \mathrm{C}>\mathrm{T}$ affects mRNA stability.

Pharmacogenet Genomics 15 (10): 693-704

19

Kim RB, Leake BF, Choo EF, Dresser GK, Kubba SV, Schwarz UI,

Taylor A, Xie HG, McKinsey J, Zhou S, Lan LB, Schuetz JD, Schuetz EG, Wilkinson GR (2001) Identification of functionally variant MDR1 alleles among European Americans and African Americans. Clin Pharmacol Ther 70 (2): 189-199

20 Kroetz DL, Pauli-Magnus C, Hodges LM, Huang CC, Kawamoto M,

Johns SJ, Stryke D, Ferrin TE, DeYoung J, Taylor T, Carlson EJ, Herskowitz I, Giacomini KM, Clark AG (2003) Sequence diversity and haplotype structure in the human ABCB1 (MDR1, multidrug resistance transporter) gene. Pharmacogenetics 13 (8): 481-494

$\underline{21}$ Cascorbi I, Gerloff T, Johne A, Meisel C, Hoffmeyer S, Schwab M,

Schaeffeler E, Eichelbaum M, Brinkmann U, Roots I (2001) Frequency of single nucleotide polymorphisms in the P-glycoprotein drug transporter MDR1 gene in white subjects. Clin Pharmacol Ther 69 (3): 169-174

$\underline{22}$ Leschziner GD, Andrew T, Pirmohamed M, Johnson MR (2007) ABCB1 genotype and PGP expression, function and therapeutic drug response: a critical review and recommendations for future research. Pharmacogenomics J 7 (3): 154-179 
Fiegenbaum M, da Silveira FR, Van der Sand CR, Van der Sand LC,

Ferreira ME, Pires RC, Hutz MH (2005) The role of common variants of ABCB1, CYP3A4, and CYP3A5 genes in lipid-lowering efficacy and safety of simvastatin treatment. Clin Pharmacol Ther 78 (5): 551-558

Clinical pharmacokinetics and pharmacodynamics of aliskiren. Clin Pharmacokinet 47

(8): $515-531$

26

Kivistö KT, Niemi M, Schaeffeler E, Pitkälä K, Tilvis R, Fromm MF,

Schwab M, Eichelbaum M, Strandberg T (2004) Lipid-lowering response to statins is affected by CYP3A5 polymorphism. Pharmacogenetics 14 (8): 523-525

Influence of body weight and gender on the pharmacokinetics, pharmacodynamics, and antihypertensive efficacy of aliskiren. J Clin Pharmacol

Doi:10.1177/0091270009359525

28

Verstuyft C, Schwab M, Schaeffeler E, Kerb R, Brinkmann U, Jaillon P,

Funck-Brentano C, Becquemont L (2003) Digoxin pharmacokinetics and MDR1 genetic polymorphisms. Eur J Clin Pharmacol 58 (12): 809-812

\section{Deleted: 11}

Deleted: 12

Deleted: 13 Vaidyanathan $\mathrm{S}$, Camenisch G, Schuetz H, Reynolds C, Yeh CM, Bizot MN, Dieterich HA, Howard D, Dole WP (2008)

Pharmacokinetics of the oral direct renin inhibitor aliskiren in combination with

digoxin, atorvastatin, and ketoconazole in

healthy subjects: the role of $\mathrm{P}$ -

glycoprotein in the disposition of

aliskiren. J Clin Pharmacol 48 (11): 13231338 II

14. Waldmeier F, Glaenzel U, Wirz B,

Oberer L, Schmid D, Seiberling M,

Valencia J, Riviere GJ, End P,

Vaidyanathan S (2007) Absorption,

distribution, metabolism, and elimination

of the direct renin inhibitor aliskiren in

healthy volunteers. Drug Metab Dispos

35 (8): 1418-1428 II

15. Olkkola KT, Backman JT, Neuvonen PJ (1994) Midazolam should be avoided

in patients receiving the systemic

antimycotics ketoconazole or

itraconazole. Clin Pharmacol Ther 55 (5): 481-485 II

16. Jalava KM, Partanen J, Neuvonen PJ (1997) Itraconazole decreases renal

clearance of digoxin. Ther Drug Monit 19 (6): 609-613 II

17. Wang EJ, Lew K, Casciano CN,

Clement RP, Johnson WW (2002)

Interaction of common azole antifungals

with $\mathrm{P}$ glycoprotein. Antimicrob Agents

Chemother 46 (1): 160-165 II

18. Rao US, Scarborough GA (1994)

Direct demonstration of high affinity

interactions of immunosuppressant drugs

with the drug binding site of the human

P-glycoprotein. Mol Pharmacol 45 (4):

773-776 II

19. Kajosaari LI, Niemi M, Neuvonen M, Laitila J, Neuvonen PJ, Backman JT (2005) Cyclosporine markedly raises the plasma concentrations of repaglinide. Clin Pharmacol Ther 78 (4): 388-399 II

20. Tapaninen T, Backman JT, Kurkinen

KJ, Neuvonen PJ, Niemi M (2010) Itraconazole, a P-glycoprotein and

CYP3A4 inhibitor, markedly raises the plasma concentrations and enhances the renin-inhibiting effect of aliskiren. J Clin Pharmacol in press II

21. European Public Assessment Report for Rasilez. Available from

URL:http://www.emea.europa.eu/humand ocs/Humans/EPAR/rasilez/rasilez.htm.

Accessed Mar 11, 2010 II

22. Greiner B, Eichelbaum M, Fritz P, Kreichgauer HP, von Richter O, Zundler

J, Kroemer HK (1999) The role of intestinal P-glycoprotein in the

interaction of digoxin and rifampin. $\mathbf{J}$

Clin Invest 104 (2): 147-153 II

23. Niemi M, Backman JT, Fromm MF,

Neuvonen PJ, Kivistö KT (2003)

Pharmacokinetic interactions with

rifampicin : clinical relevance. Clin Pharmacokinet 42 (9): 819-850 If 
Kerb R, Fromm MF, Brinkmann U, Eichelbaum M, Brockmöller J, Cascorbi I, Roots I (2002) Modulation of steady-state kinetics of digoxin by haplotypes of the P-

glycoprotein MDR1 gene. Clin Pharmacol Ther 72 (5): 584-594

30

Sakaeda T, Nakamura T, Horinouchi M, Kakumoto M, Ohmoto N, Sakai

T, Morita Y, Tamura T, Aoyama N, Hirai M, Kasuga M, Okumura K (2001) MDR1

genotype-related pharmacokinetics of digoxin after single oral administration in healthy Japanese subjects. Pharm Res 18 (10): 1400-1404

31

Chowbay B, Li H, David M, Cheung YB, Lee EJ (2005) Meta-analysis of the influence of MDR1 C3435T polymorphism on digoxin pharmacokinetics and MDR1 gene expression. Br J Clin Pharmacol 60 (2): 159-171 
Table 1 Pharmacokinetic variables of and plasma renin activity response to a single 150-mg oral dose of aliskiren in healthy subjects homozygous for the $A B C B 1$ c.1236C-c.2677G-c.3435C (CGC/CGC_genotype; $n=11$ ) or c.1236T-c.2677T-c.3435T (TTT/TTT genotype; $n=11)$ haplotype

\begin{tabular}{|c|c|c|c|c|}
\hline \multirow[t]{2}{*}{ Variable } & \multicolumn{2}{|c|}{$A B C B 1$ genotype } & \multirow{2}{*}{$\begin{array}{l}\text { Geometric mean ratio } \\
(95 \% \mathrm{CI})\end{array}$} & \multirow[t]{2}{*}{$P$ value } \\
\hline & CGC/CGC & TTT/TTT & & \\
\hline \multicolumn{5}{|l|}{ Aliskiren } \\
\hline $\mathrm{C}_{\max }(\mathrm{ng} / \mathrm{ml})$ & $98(67,143)$ & $111(76,163)$ & $1.14(0.66,1.96)$ & 0.631 \\
\hline $\mathrm{t}_{\max }(\mathrm{h})$ & $1(0.5-5)$ & $0.5(0.5-5)$ & & 0.495 \\
\hline $\mathrm{t}_{1 / 2}(\mathrm{~h})$ & $23.9(19.0,28.8)$ & $22.5(17.6,27.4)$ & $-1.4(-8.3,5.5)^{*}$ & 0.684 \\
\hline $\mathrm{AUC}_{0-72}(\mathrm{ng} \cdot \mathrm{h} / \mathrm{ml})$ & $419(289,608)$ & $429(296,622)$ & $1.02(0.60,1.74)$ & 0.927 \\
\hline $\operatorname{AUC}_{0-\infty}(\mathrm{ng} \cdot \mathrm{h} / \mathrm{ml})$ & $443(301,652)$ & $449(306,661)$ & $1.01(0.58,1.76)$ & 0.960 \\
\hline Ae $(\mathrm{mg})$ & $0.499(0.335,0.742)$ & $0.516(0.347,0.767)$ & $1.03(0.58,1.83)$ & 0.905 \\
\hline $\mathrm{Cl}_{\text {renal }}(1 / \mathrm{h})$ & $1.75(1.48,2.06)$ & $1.71(1.45,2.01)$ & $0.98(0.77,1.23)$ & 0.842 \\
\hline \multicolumn{5}{|c|}{ Plasma renin activity (ng/ml/h) } \\
\hline At baseline & $1.73(0.96,2.50)$ & $2.38(1.61,3.15)$ & $0.66(-0.43,1.75)^{*}$ & 0.222 \\
\hline At $4 \mathrm{~h}$ & $0.01(-0.09,0.11)$ & $0.09(-0.01,0.19)$ & $0.08(-0.06,0.22)^{*}$ & 0.251 \\
\hline At $24 \mathrm{~h}$ & $1.08(0.51,1.65)$ & $1.36(0.79,1.92)$ & $0.28(-0.52,1.08)^{*}$ & 0.479 \\
\hline
\end{tabular}

$\mathrm{C}_{\max }, \mathrm{AUC}$, and Ae data are estimated marginal mean $(95 \% \mathrm{CI})$ adjusting for weight; $\mathrm{t}_{1}, \mathrm{Cl}_{\text {renal }}$, and plasma renin activity are estimated marginal mean $(95 \% \mathrm{CI}) ; \mathrm{t}_{\max }$ are median (range). CI, Confidence interval; $\mathrm{C}_{\max }$, peak plasma concentration; $\mathrm{t}_{\max }$, time to $\mathrm{C}_{\max }$; $\mathrm{t}_{1 / 2}$, elimination half-life; $\mathrm{AUC}_{0-72}$, area under the plasma concentration-time curve from 0 to $72 \mathrm{~h} ; \mathrm{AUC}_{0-\infty}$, area under the plasma concentration-time curve from time 0 to infinity; Ae, amount excreted into urine within $12 \mathrm{~h} ; \mathrm{Cl}_{\text {renal }}$ renal clearance; Baseline, before the administration of aliskiren.

* Mean difference $(95 \% \mathrm{CI})$

\begin{tabular}{|l|}
\hline Deleted: with \\
\hline Deleted: /C \\
\hline Deleted: /G \\
\hline Deleted: /C \\
\hline Deleted: /T \\
\hline Deleted: /T \\
\hline Deleted: /T \\
\hline Deleted: genotype \\
\hline $\begin{array}{l}\text { Deleted: /II } \\
\text { mean differenceI }\end{array}$ \\
\hline
\end{tabular}




\section{FIGURE LEGEND}

Fig. 1 Weight-adjusted mean \pm SEM plasma concentrations of aliskiren (A) and mean \pm SEM plasma renin activity (B) after a single 150-mg oral dose of aliskiren in subjects homozygous for the $A B C B 1$ c. $1236 \mathrm{C}-\mathrm{c} .2677 \mathrm{G}-\mathrm{c} .3435 \mathrm{C}$ ( $n=11$; open circles) or $A B C B 1$ c.1236T-c. 2677T-c.3435T ( $n=11$; solid circles) haplotype. The inset in part A shows aliskiren plasma concentration data on a semi-logarithmic scale

\begin{tabular}{l} 
Deleted: with \\
Deleted: /C \\
Deleted: /G \\
Deleted: /C \\
Deleted: $/ \mathrm{T}$ \\
Deleded: $/ \mathrm{T}$ \\
\hline
\end{tabular}




\begin{tabular}{|c|c|c|}
\hline Page 18: [1] Deleted & tapatui20 & 4/20/2010 3:35:00 PM \\
\hline
\end{tabular}

MN, Dieterich HA, Howard D, Dole WP (2008) Pharmacokinetics of the oral direct renin inhibitor aliskiren in combination with digoxin, atorvastatin, and ketoconazole in healthy subjects: the role of P-glycoprotein in the disposition of aliskiren. J Clin Pharmacol 48 (11): 1323-1338

14 Waldmeier F, Glaenzel U, Wirz B, Oberer L, Schmid D, Seiberling M, Valencia J, Riviere GJ, End P, Vaidyanathan S (2007) Absorption, distribution, metabolism, and elimination of the direct renin inhibitor aliskiren in healthy volunteers. Drug Metab Dispos 35 (8): 1418-1428

15 Olkkola KT, Backman JT, Neuvonen PJ (1994) Midazolam should be avoided in patients receiving the systemic antimycotics ketoconazole or itraconazole. Clin Pharmacol Ther 55 (5): 481-485

16 Jalava KM, Partanen J, Neuvonen PJ (1997) Itraconazole decreases renal clearance of digoxin. Ther Drug Monit 19 (6): 609-613

17 Wang EJ, Lew K, Casciano CN, Clement RP, Johnson WW (2002) Interaction of common azole antifungals with P glycoprotein. Antimicrob Agents Chemother 46 (1): 160-165 

Rao US, Scarborough GA (1994) Direct demonstration of high affinity interactions of immunosuppressant drugs with the drug binding site of the human Pglycoprotein. Mol Pharmacol 45 (4): 773-776

19 Kajosaari LI, Niemi M, Neuvonen M, Laitila J, Neuvonen PJ, Backman JT (2005) Cyclosporine markedly raises the plasma concentrations of repaglinide. Clin Pharmacol Ther 78 (4): 388-399

Itraconazole, a P-glycoprotein and CYP3A4 inhibitor, markedly raises the plasma concentrations and enhances the renin-inhibiting effect of aliskiren. J Clin Pharmacol in press

21 European Public Assessment Report for Rasilez. Available from URL:http://www.emea.europa.eu/humandocs/Humans/EPAR/rasilez/rasilez.htm. Accessed Mar 11, 2010

22 Greiner B, Eichelbaum M, Fritz P, Kreichgauer HP, von Richter O, Zundler J, Kroemer HK (1999) The role of intestinal P-glycoprotein in the interaction of digoxin and rifampin. J Clin Invest 104 (2): 147-153

23 Niemi M, Backman JT, Fromm MF, Neuvonen PJ, Kivistö KT (2003)

Pharmacokinetic interactions with rifampicin : clinical relevance. Clin Pharmacokinet 42 (9): 819-850 
24 Tapaninen T, Neuvonen PJ, Niemi M (2010) Rifampicin reduces the plasma concentrations and the renin-inhibiting effect of aliskiren. Eur J Clin Pharmacol

Doi:10.1007/s00228-010-0796-3 